\title{
African and Western approaches to the moral formation of Christian leaders: The role of spiritual disciplines in counteracting moral deficiencies
}

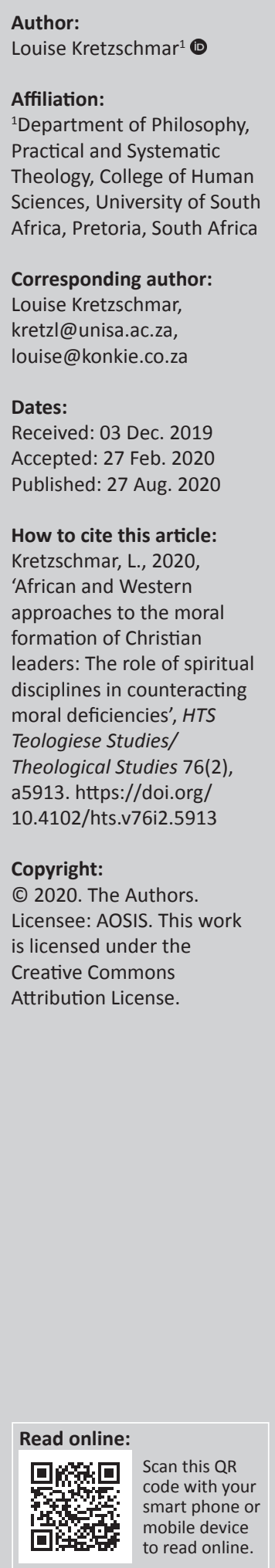

This article begins with a brief outline of current African and Western contexts, and the moral predicaments in which leaders in South Africa find themselves. The research problem addressed is how the spiritual maturity and moral excellence of Christian leaders can be advanced. The methodology employed draws on African and Western cultural and Christian traditions of moral formation. Whilst some common means of moral formation are discussed, particular attention is given to the role of spiritual disciplines. The article aims to address the following question: 'how do leaders become the kind of people who will make good and right decisions, live moral lives, contribute to the life and work of the church, care for others and the environment, and pursue social justice?' Three clusters of moral deficiencies are discussed, including pride, vainglory (self-glorification or narcissism) and greed, together with the spiritual disciplines that can counteract them. The central argument is that spiritually mature and morally excellent leaders can address more effectively the moral challenges facing the church and South African society.

Contribution: This transdisciplinary article contributes to the HTS's theological research by combining the academic disciplines of Christian Spirituality and Theological Ethics with particular reference to leadership formation. It further contributes to academic contextual discourse by evaluating African and Western traditions of moral formation and advancing practical means of addressing leadership deficiencies.

Keywords: Spiritual formation; Moral formation; Formation in Africa; Formation in the West; Christian leaders; Spiritual disciplines; Moral deficiencies; Pride; Vainglory (narcissism); Greed.

\section{Introduction}

An earlier version of this article was presented at a conference on Christian leadership jointly hosted by the Theological Society of South Africa and the Christian Leadership in Context Cluster ${ }^{1}$ in June 2019. The theme of the conference was taken from the intriguing verses from Matthew 19:30 and 20:16: 'But many who are first will be last, and the last will be first' and 'So the last will be first, and the first will be last'. The article was written within the wider southern African political context in which the Zimbabwean President Robert Mugabe was ousted in November 2017, and in February 2018, Jacob Zuma was persuaded to vacate the South African presidency. In their compulsion to be 'first' 'Big Men' and to remain in power, these leaders trampled those they claimed to serve (Kretzschmar 2019). Once removed from their positions, they found that they were no longer 'first'. It is unclear whether, and to what extent, such leaders and their supporters would be called to account for their nefarious and deeply damaging actions (ex-president Mugabe died on 06 September 2019). It also remains to be seen whether those who are currently the 'last', that is, those excluded from the responsibilities and rewards of leadership and citizenship, will ever become the 'first' in this world.

\section{The research problem: Why this article?}

In both African and Western countries, leaders in different sectors of society are facing a myriad of challenges. These include internal political challenges to their positions, global tensions between the 'superpowers' and those countries they support, Brexit, social migration, economic

1.This Christian Leadership in Context Cluster consists of academics from the University of South Africa and the Gesellschaftfür Bildung und Forschung in Europa (GBFE). Their academic exchanges and cooperation have resulted in several research publications and the facilitation of postgraduate research between Africa and Europe and beyond. 
inequality, social conflict, unemployment and the contested role of faith leaders within secular societies. Within faith communities, including the Christian community, sound leadership is also a vital issue.

Although the number of Christians in Africa is growing (recent estimates cite nearly 600 million adherents), the maturity of their Christian faith is not sufficiently evident. Whilst some churches are flourishing and ministering within their communities (Ntlha 2009:287-297), in other churches conflicts, selfishness and moral scandals are visible. Moreover, many churches have not had the positive influence on the African continent they ought to have had, as corruption, stagnant economies, lack of justice and service delivery, violence against women and children, environmental degradation and civil conflict persist. In Africa and elsewhere, the faith experience of some Christian leaders appears to be shallow or superficial, insufficiently related to the social contexts in which they live, or lacks a commitment to integrity and social justice (Maluleke 2010a; eds. Mugambi \& Nasimiyu-Wasike 1999; Sebahene 2017). As a result, the leadership of the corrupt is legitimated, enabling them to evade being held accountable for their actions. This reveals the personal and communal importance of spiritual formation, moral character development and social ministry. If the spiritual maturity, moral goodness and courage of Christian leaders can increase significantly, they will be able to facilitate better the spiritual growth of the believers entrusted to their care. These believers, in turn, will be able to engender healing, restoration and justice in their family and social contexts.

This author does not believe that leadership is everything or that 'everything rises and falls on leadership'. This is because the influence and role of ordinary people is vital, as witnessed in their mass resistance to various forms of injustice. Examples include the resistance to apartheid and, more recently, the 'Zuma must fall' protests. Also important are the empowerment of a wider range of leaders and an awareness of interdependence of leadership. However, because of the influence they wield, the role of leaders remains important. Unless they are morally formed, they cannot live exemplary lives or help to form others. On the one hand, this leads to increased frustration and resistance on the part of those subjected to the rule of irrational, unethical and incompetent leaders and, on the other hand, to apathy or withdrawal.

This article focuses on the means of advancing the spiritual maturity and moral character of Christian leaders, whether they are active within the church and para-church organisations or within government, business, labour unions, non-governmental organisations (NGOs) or community organisations. Whilst the author recognises the moral (and immoral) influence of organisations and social groups, the focus of this article is on the ongoing formation of Christian leaders. More specifically, the article aims to address the following question: how can leaders become the kind of people that will make right and good decisions, live moral lives, contribute to the life and work of the church, care for others and the environment, and pursue social justice?

\section{Definitions, aims and methodology}

The spiritual formation of leaders means their formation into the likeness of Christ. Leech (1980:5) argues that spiritual formation involves 'confrontation, exploration, and struggle, and its goal is maturity in Christ'. A spiritual director, Jill Manton, stresses encounter and cooperation with God that is a 'gradual life-long shaping of mind and spirit' in individual, communal and social contexts that includes struggle, humour, faith and courage (Manton 1997:2-3).

From a Christian perspective, spiritual formation is initiated by our acceptance of Christ's offer of salvation, whether this acceptance takes the form of an instantaneous conversion experience, or a gradual experience of conversion. It ought to continue with a process, traditionally termed sanctification, of increasing spiritual maturity or growth. The 'marks' of Christian spirituality are as follows: 'reconciling and integrative', 'incarnational', 'rooted in scripture and nourished by prayer', 'costly and self-giving', 'life-giving and liberative', 'rooted in community' and the Eucharist, 'expressed in service and witness' and 'waiting for God's surprising initiative' (eds. Amirtham \& Pryor 1989:154-156; see also Hudson 1995,1998).

This author understands moral formation to be an aspect of spiritual formation; it promotes the development of Christian moral thinking, character, relationships and behaviour (Wright 2010). Hence, being formed into the likeness of Christ (spiritual formation) must lead to the moral formation of leaders. Our theological reflection and moral understanding of how God expects us to respond to the pressing ethical issues of our times influence this process of formation. Therefore, ethical reflection on issues, such as political governance, business ethics, wealth and poverty, family life, etc., ought not to be separated from the moral formation of believers, church communities or Christian leaders (Kretzschmar 2004, 2012; Nkansah-Obrempong 2013:22-27, 109-113, 126-131; Wright 2010).

The article firstly outlines several general means of moral formation and then focuses on the role of spiritual disciplines in counteracting specific moral deficiencies, particularly in the South African context. To this end, the methodology draws on African and Western cultural and faith traditions that seek to foster formation, development or discipleship.

To begin with African sources, one finds many discussions of African Theology (e.g. Bujo 1992, 2010; ed. Stinton 2010) and Black Theology (e.g. Mosala \& Tlhagale 1986; Motlhabi 2008). Researchers such as Kudadjie (1996), Pato (1996, 2002), Olupona (ed. 2001), Mbuy-Beya (2010:65-76) and many others (e.g. eds. Abraham \& Mbuy-Beya 1994) have written on African spirituality. Texts on African Christianity (e.g. Maluleke 2010a, 2010b; Phiri et al. 2016) and African ethics 
(e.g. Bujo 2001; Kunhiyop 2008; Morove 2009; NkansahObrempong 2013) also contribute to our understanding of Christian faith in an African context. For example, Bujo (2001:12-14, 27, 101-135, 175-203) is critical of the dominance of Western 'monocultural' morality and stresses the relevance of African thought and experience for people in other contexts. Bujo (2001:26) stresses that African ethics tends to focus on what is good for the person and community in concrete situations rather than on abstract principles. Comparisons between traditional African, secular, Western and Christian spirituality and morality have been undertaken by researchers such as Kretzschmar (2008:63-96), Kunhiyop (2008) and Van der Walt (2003:51-71).

What is less often analysed is the practical means of spiritual (and moral) formation. For example, in the Anthology of African Christianity (Phiri et al. 2016), a book of over 1200 pages, only one article (Kaunda 2016:933-939) specifically addresses leadership formation and education in African Christianity, and it deals mainly with theological education. Other exceptions include a book edited by Mugambi and Nasimiyu-Wasike (eds. 1999), in which Getui (1999:59-72), Kinoti (1999:73-82) and Mwikamba (1999:83-106; see also Kretzschmar 2004:90-91) have contributed chapters. However, the most useful sources I have discovered are those of Bansikiza (2001) and Bruner (2014:309-332), to which I turn below.

The Western Christian sources that I employ, especially those on formation and spiritual disciplines, include Calhoun (2005), Foster (1978), Vest (2000) and Willard (1988, 1998). Even though I grew up in the Dutch Reformed Church, and then became first a member of the Baptist Union of South Africa, and later the Baptist Convention of South Africa, I use several Catholic sources. The reason for this is that Catholic writers draw upon a very rich historical and contemporary tradition of spiritual formation. I have also benefited from the spiritual direction of three Catholic sisters and attended several retreats.

The second element of the methodology employed in this article is that of reflection on experience. For nearly 40 years, I have taught in various schools and universities and worked with a range of students and colleagues. I have also been attentive to public issues, involved with communities and have been an active member of a number of churches. Over the last 28 years, I have been a member of the same Bible study group that meets once a week.

Earlier publications analysed the need for spiritual and moral formation of leaders (Kretzschmar 2002, 2006, 2007) and discussed formation in the context of ministerial education (Kretzschmar 2015; Kretzschmar \& Tuckey 2017; see also Naidoo 2016). The need for mature Christian believers to be formed (so that they can engage in a credible and wise way with church and state challenges) was also discussed (Kretzschmar 2012), and I identified ways in which lay leaders could be helped to become mature practitioners of their faith in work contexts (Kretzschmar 2014, 2016).

The relationship between tuition and research is a symbiotic one. The writing of study material for students (e.g. the CGM304V study guide, currently under revision; Kretzschmar 2005) and my interaction with those students who have completed undergraduate or postgraduate modules or theses in the fields of Christian ethics, spirituality and leadership have further deepened my understanding of what genuine Christian leadership entails. Hence, one's tuition and research influence each other, raise new questions and ought to deepen one's spiritual and theological-ethical insights.

\section{Some general means of moral socialisation and formation}

In her book, Restoring Moral Formation in Africa, Bansikiza (2001:xii) defines moral formation as 'helping people to grow in goodness by avoiding what dehumanizes oneself and others'. Key elements of this formation are the person's growth in self-awareness, self-mastery (self-control), the proper use of freedom, being willing to take moral responsibility for one's actions and generous self-giving (Bansikiza 2001:11, 51-53, 76). In essence, moral socialisation is the means whereby our families and society inculcate certain attitudes and actions, and discourage others.

Bansikiza (2001) draws on both traditional African means of formation and those emphasised in the Christian tradition. She stresses the role of family and cultural life in 'bringing up well-behaved persons capable of serving their communities in a worthy manner' (Bansikiza 2001:14). As Kunhiyop (2008:7-26) does, she stresses the importance of proverbs, folk tales and riddles. In addition, the moral examples set by adults in the community, especially by parents and other influential family members, are central to encouraging the formation of children and young people. The Christian life needs to incorporate the moral values nurtured in families and cultures (Bansikiza 2001:39). Cultural virtues such as 'honesty, teamwork, generosity, concern for others, and reliability' need to be internalised, and negative attitudes and actions such as 'selfishness, jealously, envy, cruelty and laziness' need to be discouraged (Bansikiza 2001:18). Similarly, amongst the Shona people, the vices to be avoided include 'abuse, lying, deceit, stealing, adultery, drinking, violent quarrelling, pride, jealousy, covetousness, hatred, ingratitude, anger, negligence, weakness, assault, provocation and selfishness' (in Van der Walt 2003:53). No family is perfect, but healthy family life is a key means of spiritual and moral formation. Children learn from parental teaching and, better still, from the good behaviour of significant adults. Equally, the example of adults who are drunk, indifferent or violent can also be formative, but in a negative way.

Within the church, too, prospective leaders are socialised to think and act in particular ways. It is here that they can learn 
to love God and desire to emulate God's nature whilst internalising respect and consideration for other people. In the Old Testament, Jews were instructed to live according to God's statutes and to teach them to their children (Dt 4:1, 9; 6:4-9; Pr 22:6). In the New Testament, believers are instructed to leave behind their previous immoral lives and to put on 'the new self' (Col 3:5-10).

Moral formation must avoid both indoctrination (excessive and rigid moral control) and relativism (insufficient loving guidance and support). Children and young people need to imbibe moral norms, such as being fair and caring towards others, and be guided to develop sound attitudes and to act with honesty and respect. Van der Ven (1998:43-79) points out that if children are properly (not abusively) disciplined, they progressively learn self-discipline or self-regulation. In addition, the emotional formation of children is crucial for their moral development because love, affection, stability and security enable the growth of 'openness and trustfulness' (Bansikiza 2001:10). Tragically, in South Africa and other parts of the world, many children live in dire poverty, many are orphans, and yet others are neglected or abused. Our society has sown the seeds of abuse and neglect and is now reaping a harvest of violent acts issuing from rage, pain and frustration.

Other means of moral influence, for good or bad, include that of friends and peers, the media and formal education. In traditional African culture, argues Bansikiza (2001:23), groups of young people of a similar age assist one another to imbibe the values of their community and to take on responsibilities within their families and communities. The breakdown of many cultural, clan and family structures means that traditional values are not transmitted well. Mungwini (2011:774-787) even questions whether traditional means of moral formation could be restored within a context of modernity that has denuded the traditional worldview that gave rise to these formational practices.

Similarly, whilst schools ought to be places where the minds, skills, relationships and character of children are developed, dysfunctional schools and uncommitted (or depraved) teachers impede their development. Furthermore, the content of some sources of public and social media could influence many people to accept crudity, violence, sexual promiscuity, the ruthless pursuit of wealth and power, contempt and cruelty as valid lifestyles.

Finally, what of the role of the human will? Can Christian leaders say that they have achieved self-mastery? Some people are very determined and focused, even driven, to achieve what they have chosen. However, is what they have chosen worth pursing, and what effects will these choices have on others? Other people tend to be passive, simply conforming to 'the ways things are', enabling evil to flourish.

It is vital that leaders consciously allow the Holy Spirit to redeem their will and the inner voice of their conscience.
Instead of being ignored or distorted, our God-given moral conscience and will need to be sharpened so that Christian leaders intuitively revolt against what is ugly, evil and destructive. It is for this reason that Vest (2000:62) argues that Christians should not try to control or repress desire but to train desire so that they long for what is right and good. In Psalm 34, we read:

Which of you desires life, and covets many days to enjoy good? Keep your tongue from evil, and your lips from speaking deceit. Depart from evil, and do good; seek peace, and pursue it. (vv. 12-14)

Similarly, Jesus said, '[ $[b]$ lessed are those who hunger and thirst for righteousness, for they will be filled' (Mt 5:6; my emphasis).

Within all societies, moral censure (e.g. guilt and shame), law, punishment, detention and processes of restoration are used to control wrongdoing and protect society. However, these instruments can only be effective when law enforcement agencies such as the police, courts and prisons function optimally. Within traditional African culture, restorative (as opposed to punitive) justice was much emphasised because of the importance on restoring harmony within the community. The extent to which new forms of restorative justice could be implemented in society is an important debate, as is the work of those engaged in small-scale 'prison ministry' and larger projects aimed at rehabilitating those in prison. Finally, the wider social issues such as massive economic inequalities, violence and unemployment must be reduced considerably if people are to thrive and civil society is to function properly.

\section{Western and African understandings of spiritual disciplines}

Spiritual disciplines or exercises include many elements such as prayer, fasting, worship, service, simplicity and social advocacy. They require both spiritual and physical (often bodily) diligence. Foster (1978:6) explains that spiritual disciplines 'allow us to place ourselves before God so that $\mathrm{He}$ can transform us'. The soul, 'that component of the total person which coordinates all of the capacities and dimensions of the human being' (Willard 1998:21), needs to be restored by God. This means that trying assiduously to practise spiritual disciplines by means of human effort alone, or insisting legalistically that others practise them in the way we think best, is to misunderstand their purpose. Rather, the spiritual disciplines are means by which believers consistently invite the Holy Spirit to transform their thinking, habits, character and behaviour - hence the common use of the metaphor of a journey in the literature on Christian formation.

\section{Western Christian models and practices of the spiritual disciplines}

Throughout the history of the Church, various spiritual disciplines have been emphasised, for example, in the Eastern 
Orthodox and Catholic traditions. Following the Reformation, less emphasis was placed on them as a means of formation. This meant that, in the context of many local churches, the spiritual disciplines were individualised and unrelated to the 'harsh and complex social realities' in which believers lived (Kretzschmar 2004:100). The Reformers' and many of their successors' very strong emphasis on justification by faith resulted in less stress being placed on the actions that ought to result from faith, and the process of discipleship. Hence, Dallas Willard (cited in Foster \& Smith 1990:13-18) has written persuasively of the 'cost of non-discipleship', the negative results of the failure of the church to 'make disciples' (Mt 28:19-20).

In recent years, several researchers have emphasised the importance of spiritual disciplines, often producing their own lists of these. They include Richard Foster's discussion in the Celebration of Discipline (which firstly appeared in 1978), which reawakened the interest of many Protestants in spiritual disciplines. He arranges 12 disciplines in three groups, namely, inner, shared or corporate, and outer disciplines. Willard (1988:162) listed 16 spiritual disciplines in two groups: the disciplines of abstinence and engagement. Holm (2008:159-175) extended the approach of Dietrich Bonhoeffer, as outlined in his book Life Together (1959). Five elements are included: (1) Community, (2) The Day Together (including the reading of Scripture, hymn-singing, communal prayer and hospitality), (3) The Day Alone (including solitude, silence, meditation, intercession and discernment), (4) Service (practices that build community and allow others to flourish) and (5) Confession and the Lord's Supper. Another approach is that of Calhoun (2005) in her book, entitled Spiritual Disciplines Handbook. Calhoun (2005) uses the acronym WORSHIP:

- Worship.

- Open myself to God.

- Relinquish the false self.

- Share my life with others.

- Hear God's words.

- Incarnate the love of Christ.

- Pray. (n.p.)

Within this insightful and practical book, she outlines over 60 'practices that transform us', providing useful explanatory charts, questions for reflection, spiritual exercises and additional resources.

\section{African Christian understandings and practices of spiritual disciplines}

Within African contexts, I have not found many detailed discussions on spiritual disciplines in academic literature. One exception is an article by Bruner (2014:309-332), who discusses the late colonial period (1930-1955) in Southern Uganda, a time of migration, urbanisation, social dislocation, family disintegration and political dissention. He discusses the way in which the Anglican Balokole [saved ones] in the East African revival used various spiritual disciplines to reorder their homes, families and lives.
They formed fellowship groups, attended Sunday church services and 'met to pray, read, and discuss the Bible, confess their sins, sing hymns, and "walk in the light" with one another' (Bruner 2014:321). Marriages and families were protected and strengthened, inter-ethnic marriages were encouraged instead of the separation of families because of migrant labour, 'sadness, hatred, violence, and secrecy' were replaced by 'peace, openness, and happiness' in the home, and dedicated child-rearing was encouraged (2014:322-323). However, Bruner does not discuss the wider social effects of the experience and witness of the Balokole.

Even though the academic discussion is limited, many of the spiritual disciplines are practised. In the following, I discuss practices with which I have become familiar over many years of visiting a number of African churches (e.g. in Ghana, Kenya and Nigeria), and by being a member of multiracial or black churches in Mthatha and Pretoria. In many churches, there is a keen awareness of God's presence, an emphasis on prayer, and on the family and community, along with joyous celebration and a reliance on God's power in times of both struggle and success.

\section{Three examples of the formative effects of particular spiritual disciplines}

Below, I focus on a few of the key moral challenges facing Christian leaders in South Africa, and the role that a dedicated practice of particular disciplines can play in their spiritual formation. Magesa (2010) argues that:

Human beings obtain the life that Christ offers not only when they are freed from the invisible chains of hatred, anger, malice, pride and contempt for God and each other - in a word, from wrong doing - but also from the visible chains of disease, poverty and ignorance - the concrete results of human failing. (p. 76)

Below, out of many, three 'clusters' of moral evil and some of the spiritual disciplines that can reduce and even destroy their power are discussed.

\section{Individual dimensions}

The first cluster is the pride, arrogance and indifference to the rights and needs of others, and the abuse of power that appears to have become endemic to South Africa. Pride ought not to be confused with legitimate self-esteem; it is characterised by arrogance, self-satisfaction, conceit and self-importance. Pride and arrogance separate leaders from God, and they damage human relationships, social interaction and the natural world. Pride is seen in the rude attitudes and uncooperative, dismissive and slow responses of leaders in the political sphere, from cabinet ministers to minor officials. Ordinary people experience the effects of pride in business circles, the workplace, government offices and even in shops. This arrogance and abuse of power is psychologically oppressive, and it damages society, resulting in important 
institutions, departments, systems and delivery processes becoming dysfunctional.

Pride further distorts human reasoning abilities because it assumes that we do not need God but are independent and self-sufficient. According to Vest (2000), pride is:

[T] he attempt to create our own world for ourselves, to embark on the path of perception as we define it, and finally to separate ourselves definitively from God. [It is] ... the great sin of blasphemy - contempt for God. (p. 80)

The spiritual discipline of prayer is especially effective in mitigating pride. However, here we are not referring to the false prayer offered by the Pharisee described by Jesus in Luke 18:9-14, as this type of prayer is governed by the pride that keeps us away from God - as well as from a true knowledge of others and ourselves. What, then, is prayer? Foster (1978) notes:

Real prayer is life-creating and life-changing ... to pray is to change. Prayer is a central avenue God uses to transform us. If we are unwilling to change, we will abandon prayer as a noticeable characteristic of our lives. The closer we come to the heartbeat of God, the more we see our need of God and the more we desire to be conformed to Christ. (p. 30)

Prayer, says Magesa (2010:76), is a 'conversation with God' and it is vital in the process of formation. It can be both private and corporate, requires trust and disciplined practice, and brings hope, joy and courage. It is an acknowledgement of our human need for God, but genuine prayer must not lead to the abandoning of human responsibility. Prayer, especially when accompanied by silence and solitude (Willard 1998:16), both draws us into intimacy with God and 'moves us up and out into our world' (Calhoun 2005:203). The indispensability of prayer is seen, for example, in the practices of David (Ps 63:1), Jesus himself (Mk 1:35), the early disciples (Ac 6:4) and countless believers across the globe.

Prayer counteracts the moral failings of pride and arrogance because they cannot be sustained in God's presence. As believers are exposed to the purifying and gracious light of God's gaze, the pride and arrogance that lie at the root of the abuse of power are exposed. Prayer makes people aware of their dependence on God for everything they have, their human vulnerability and their need for others. As it produces a heightened awareness of God and the self, those who pray regularly and deeply can gain new insights about both their gifts and faults. Often, though, human beings only abandon pride and turn to God in times of great difficulty.

In African contexts, prayer, both personal and communal, is strongly emphasised. Given the common experiences of poverty, helplessness and marginalisation in many African communities, much is made of God's power to save, intervene and help. In church services and small groups, joint, loud, spontaneous and simultaneous prayer is commonly heard, which is unusual in the West except in Charismatic and Pentecostal churches. Night prayer and vigils are practised several times a year.

In African churches, the practice of communal and loud verbal prayer means that there is less emphasis on prayer as listening. Similarly, disciplines such as solitude, silence and meditation are not common because of the communal nature of African culture and the overcrowding of African urban centres. Nevertheless, when experienced, these disciplines are very revealing and transformative. This is illustrated in the following anecdote: a few years ago, a colleague of mine led a day of silent prayer and meditation in the Mamelodi township (in Pretoria). She shared what a young woman had said to her afterwards: 'I never knew I was talking so much. I talked to God all the time; it was hard to be quiet and to listen'.

As noted earlier, genuine prayer leads to change, a transformation of consciousness and lifestyle. This is seen in Jesus' teaching in Luke 6:12-29, where the 'golden rule', the 'narrow gate', assessing people's words according to their 'fruit' (actions), the dangers of self-deception, and being 'doers' rather than merely 'hearers' of God's Word are explained. Therefore, prayer must not be passive; it needs to be accompanied by personal and communal (of the faith community) moral responsibility, initiative and agency. Strengthened and emboldened by God, Christians are expected to resist wrongdoing in society and actively promote what is right or good.

\section{Communal dimensions}

The second cluster of sins, or moral vices, to which leaders are prone comprises self-glorification, self-protection, deceit and unethical patronage. The damaging sin of self-glorification (classically termed vainglory, see Vest 2000:80-81; Mt 6:1-8) is common in those who are narcissistic (self-centred), and the consequences of the actions of such leaders are dire for their communities.

Kilian (2018:33-34) argues that narcissistic leaders tend to abuse power because they fear dependence or the loss of power. They have a sense of entitlement, feed on admiration and adulation, are proud, consider themselves to be special and believe in their own brilliance (2018:35; see also De Young 2009:59-77). This self-glorification on the part of leaders is seen in their 'single-minded pursuit of success, achievement, and ambition' (Vest 2000:80), and their inability to attend to the needs and rights of others. In addition, such leaders tend to claim credit for whatever has been carried out well whilst blaming others for any problems resulting from the leader's own decisions and actions. These leaders are further deceitful and lie to themselves and others to conceal their wrongdoings. Leaders who abuse their power in any sector of society cause untold harm to families, communities, churches, companies and countries. Speaking about the expresident, the exiled Zimbabwean journalist, Peta (2019), put it as follows: 
In my view Mugabe lost the plot when, after tasting power, he convinced himself he would rule 'until God takes me'. To achieve his life-presidency goal, he would exterminate anything that stood in his way. He would pursue any policy that would help him cling to power, no matter how politically innumerate nor [sic] economically illiterate. (n.p.)

Patronage, as we have seen in South Africa under both the previous and current political dispensations advantages the few at the expense of many. Corrupt and vainglorious leaders enable specific groups and families to gain unfair access to contracts, plum positions and opportunities to misuse their power. Leaders who are narcissistic destroy trust, collegiality, human well-being and the functionality of society. Within the Christian faith communities, genuine fellowship, trust, cooperation and joint ministry are broken down, if not destroyed.

Along with psychological counselling in extreme cases, the practice of the spiritual disciplines of confession and guidance are needed to train Christian leaders to abandon or at least radically amend their narcissistic tendencies as both their feelings of shame and envy are exposed.

The spiritual discipline of confession counteracts selfglorification because it requires leaders to admit their vainglory and deceitfulness to God and others. For centuries, confession to a priest was part of Christian faith. In the Catholic Church, it is still practised amongst faithful adherents. In most other churches, this discipline is not practised, except perhaps in a situation of pastoral counselling or within a Bible study/cell group that is very close-knit and where the members trust each other.

Confession is both a private matter between the individual and God (1 Tm 2:3-5) and a matter of fellowship between believers (Ja 5:16; Jn 20:23). Confession needs to follow growing self-awareness and bring inner healing to human hurt and pain. Confession also diminishes the conceit and deceit (lies) on which self-glorification and ruthless ambitions are based. 'For a good confession, three things are necessary: an examination of conscience, sorrow, and a determination to avoid sin' (St Alphonsus Liguori, 'A good confession' in an anthology entitled To any Christian, published in 1964 by Burns and Oates in London, cited in Foster 1978:132).

Confession also needs to be accompanied by apology, forgiveness and restitution, without which the sound human relationships that are essential to genuine fellowship cannot flourish. Confession is not cheap reconciliation. It is based on truth and honesty, and it requires leaders to take personal responsibility for their disordered desires, false selfperception and destructive actions. One cannot just confess to anyone; recipients need to be chosen carefully. Those who hear confessions must remember their own sinfulness and dependence on God, and thereby avoid reacting in a selfrighteous manner.

Another spiritual discipline that is important here is that of guidance. Guidance requires concentrated attention, together with wise, honest and constructive comment. Leaders need to listen to both the truth that God is revealing to them (see 'prayer' and 'meditation' as discussed in the 'Individual dimensions' section above) and what others are saying to them. Guidance exposes ignorance and self-deception (Mt 19:16-22; Gl 2:11-21) and reveals the negative influence that the attitudes and actions of leaders may have on others. Guidance can emerge, for example, from listening deeply to a sermon, in prayer or meditation, in what we read, in conversation, during a group consultation, in counselling and in spiritual direction - but only if leaders are willing to open themselves to the insights of others. It is for this reason that genuine (not superficial) fellowship is so important.

\section{Social dimensions}

The third cluster of sins, or moral deficiencies, examined here are greed and lust. Greed is being obsessed with money and possessions, and insatiably wanting more of them. Greed or avarice (from the Latin word avere, meaning 'to crave') is often rooted in a deep sense of insecurity and inferiority, and a psychological need to impress others with what we have. Greed has led many people in South Africa into theft, debt and corruption because they take what is not theirs or buy what they cannot afford. I am not talking here about a legitimate longing to escape from poverty, but the disordered need to possess and impress. This uncontrolled desire for money and possessions has led to theft on an enormous scale. President Ramaphosa has estimated that State capture under the Zuma administration amounted to a massive figure of over R500 billion (Omarjee 2019). This misappropriation of the country's resources has resulted in ongoing unemployment, administrative dysfunction, inequality, poverty and a massive economic deficit in South Africa. Another estimate is that 'the cost of State capture hovers at around R1.5 trillion over the second term of the Jacob Zuma administration' (Merten 2019:n.p.).

Lust is obsessive sexual desire, 'the unquenchable fire of wanting' (Vest 2000:72). Lust refers not so much to sexual desire as it does to the excessive and uncontrolled sexual passion that leads to the abuse of one's own body and the bodies and lives of others. While sexual desire that is good draws people into connection, relationship and mutual commitment, disordered sex briefly unites bodies but leaves the soul hungry, angry and alone (De Young 2009:163, 159). Lust is domination and the disordered desire to control others and is often expressed in anger and violence. When combined with greed, lust can also be seen in what some have termed the 'rape' of the environment.

In order to replace greed with generosity and fair access to economic resources, leaders need to practise the discipline of simplicity or frugality. However, in both Africa and the West, simplicity in the sense of a simple lifestyle is problematic. In the West, says Hadaway (2006):

I would suggest that consumer culture has bequeathed a legacy of acquisitiveness and competitiveness ... [A]ffluent societies have taken it as an article of economic faith that acquisitiveness 
has no legitimate upper bound ... [and this] translates into a profound sense of both aspiration and entitlement. There is very little recognition that what it is possible to achieve may not actually be consistent with a just social order. (p. 153)

Hadaway (2006) is speaking here about theological students, but what he says is true about Christians in general. In African contexts, the poverty of the many and the affluence of the few are dramatically juxtaposed. On the one hand, leaders of prosperity churches flourish in contexts of extreme poverty and deprivation, cruelly manipulating the fears and hopes of vulnerable believers. On the other hand, many of those who have escaped from poverty seek to distance themselves from their distressing memory of it, and shamelessly flaunt their wealth. Amongst Christian leaders, these aberrations ought to be replaced with actions that reduce their attachment to consumerism such as a simple lifestyle, tithing and generous giving at interpersonal levels and working for economic justice at regional, national and global levels.

To replace lust with care for other people and creation, Christian leaders need to practise the discipline of service. The spiritual discipline of service is emphasised repeatedly in the lists of disciplines mentioned above. In African churches, service is often practised in the sense of helping others at an interpersonal level. For example, especially amongst the women's departments within churches, service is expressed in visiting the sick in hospitals, raising money for a variety of projects and helping the poor. Women also seek to help each other in times of suffering because of unemployment, sickness, family problems and death. Such generous acts of compassion, together with bursary schemes, shelters for abused women and children, literacy programmes and many more, are vital means of serving others at interpersonal and community levels.

However, in my view, the spiritual discipline of service ought to be expanded beyond acts of interpersonal compassion to include social engagement and advocacy. Hankela (2017:46-71) argues that it is necessary to 'reconsider the relationship between charity and social justice'. This has, to some extent, already been recognised. In her discussion of spiritual disciplines, under the section 'Incarnate the love of Christ', Calhoun (2005:179-202) discusses the care of the earth, compassion, control of the tongue, humility, justice, stewardship and truth telling. Also, Hadaway (2006:153) speaks about changing the disposition of students to being receptive to the 'moral call of justice' and the need for a 'just social order'. These support the views of Magesa (2010:76) quoted earlier about human beings needing to be freed from the invisible and visible chains that bind them.

An example of this type of service, or advocacy for justice, was seen in the socio-economic and ecological efforts of Wangari Maathai (2004). She and many others fought against the greedy destruction of huge forests by government officials and business leaders through the Green Belt
Movement. She further facilitated the planting of literally billions of trees to heal the earth, nurture its creatures and provide economic resources for its people (Rakoczy 2017:7677). In this way, she combined her love for the environment (learnt as a child in a rural area), her scientific knowledge and her Christian faith.

This means that the practice of the discipline of service needs to be expressed in the lives of Christian leaders and communities of faith at local, regional, national and global levels. Service as social engagement includes fighting for justice, advocacy for the exploited or marginalised, working to change governmental or economic policies, engaging with the business sector, fighting to protect animals' rights, addressing widespread pollution, and using natural resources wisely.

If the spiritual perception and energy of churches remain largely restricted to conversion and do not extend sufficiently to discipleship or engagement with social and environmental matters, it is no wonder that the continent continues to be crushed under the weight of corruption, injustice and other diremaladies (Sebahene 2017). However, a richer understanding and practice of these and other spiritual disciplines will enable Christian leaders and communities of believers to repent, progressively be formed, enable faith communities to flourish and effect radical change in their societies.

\section{Conclusion}

It is important to note that spiritual and moral formation are inextricably linked, the latter being an aspect of the former. The article has argued that Christian leaders can indeed become the kind of people who could make right, good and wise decisions, live moral lives, contribute to the life and work of the church, care for others and the environment, and pursue social justice.

The rediscovery and practice of the spiritual disciplines discussed above, along with other means, such as the influence of family and culture in moral socialisation, can have a positive effect on individual leaders and their contexts. Moral sins or deficiencies, such as pride, arrogance and the abuse of power, self-glorification (vainglory), greed and lust, need to be exposed, acknowledged and abandoned, or they would continue to destroy families, churches and society. Christian leaders need to live exemplary lives and provide direction by practising these and other spiritual disciplines. Along with general forms of moral socialisation, the regular practice of spiritual disciplines is a key way in which this moral formation of Christian leaders could be facilitated. However, the spiritual disciplines need to be better understood, a wide range of spiritual disciplines need to be intentionally practised and their social advocacy needs to be exercised. In this way, believers, individually and corporately, open themselves to the work of the Holy Spirit, and Christian leaders can be empowered to act in ways that express love, and promote justice and care in churches, society and the natural environment. 


\section{Acknowledgements Competing interests}

The author declares that she has no financial or personal relationships that may have inappropriately influenced her in writing this research article.

\section{Author's contributions}

L.K. is the sole author of this research article.

\section{Ethical considerations}

This article followed all ethical standards for research without direct contact with human or animal subjects.

\section{Funding information}

This research received no specific grant from any funding agency in the public, commercial or not-for-profit sectors.

\section{Data availability statement}

Data sharing is not applicable to this article as no new data were created or analysed in this study.

\section{Disclaimer}

The views and opinions expressed in this article are those of the author and do not necessarily reflect the official policy or position of any affiliated agency of the authors.

\section{References}

Abraham, K.C. \& Mbuy-Beya, B. (eds.), 1994, Spirituality of the Third World, Orbis, Maryknoll, NY.

Amirtham, S. \& Pryor, R. (eds.), 1989, Resources for spiritual formation in theological education, WCC Programme on Theological Education, Geneva.

Bansikiza, C., 2001, Restoring moral formation in Africa, AMECEA Gaba Publications, Nairobi.

Bruner, J., 2014, 'The testimony must begin in the home: The life of salvation and the remaking of homes in the East African Revival in Southern Uganda', Journal of Religion in Africa 44(3-4), 309-332. https://doi.org/10.1163/15700666-12340021

Bujo, B., 1992, African theology in its social context, Orbis, Maryknoll, NY.

Bujo, B., 2001, Foundations of an African ethic: Beyond the universal claims of western morality, The Crossroad, New York, NY.

Bujo, B., 2010, 'The distinctives of African ethics', in D.B. Stinton (ed.), African theology on the way: Current conversations, pp. 78-89, Society for the Promotion of Christian Knowledge, London.

Calhoun, A.A., 2005, Spiritual disciplines handbook: Practices that transform us, InterVarsity Press, Downers Grove, IL.

De Young, R.K., 2009, Glittering vices, Brazos Press (Baker), Grand Rapids, MI.

Foster, R.J., 1978, Celebration of discipline: The path to spiritual growth, Hodder \& Stoughton, London.

Foster, R.J. \& Smith, J.B., 1990, Devotional classics: Selected readings for individuals and groups, Hodder and Stoughton, London.

Getui, M.N., 1999, 'Material things in contemporary African society', in J.N.K. Mugambi \& A. Nasimiyu-Wasike (eds.), Moral and ethical issues in African Christianity, pp. 59-72, Acton, Nairobi.

Hadaway, B.S., 2006, 'Preparing the way for justice: Strategic dispositional formation through the spiritual disciplines', Journal of Education \& Christian Belief 10(2), 143-165. https://doi.org/10.1177/205699710601000208

Hankela, E., 2017, 'There is a reason: A call to reconsider the relationship between charity and social justice', Exchange 46, 46-71. https://doi.org/10.1163/ 1572543X-12341427

Holm, N., 2008, 'Classroom formation \& spiritual awareness pedagogy based on Bonhoeffer's Life together', Journal of Education \& Christian Belief 12(2), 159-175. https://doi.org/10.1177/205699710801200207
Hudson, T., 1995, Signposts to spirituality: Towards a closer walk with God, Struik Christian Books, Cape Town.

Hudson, T., 1998, Invitations to abundant life: In search of life at its best, Struik Christian Books, Cape Town.

Kaunda, C.J., 2016, 'Leadership formation and education in African Christianity: Historical perspective', in I.A. Phiri, D. Werner, C. Kaunda \& K. Owino (eds.), Anthology of African Christianity, pp. 933-939, World Council of Churches, Geneva.

Kilian, M.K., 2018, Formational leadership: Developing spiritual and emotional maturity in toxic leaders, WIPF \& Stock, Eugene, OR.

Kinoti, H., 1999, 'African morality: Past and present', in J.N.K. Mugambi \& A. NasimiyuWasike (eds.), Moral and ethical issues in African Christianity, pp. 73-82, Acton, Nairobi.

Kretzschmar, L., 2002, 'Authentic Christian leadership and spiritual formation in Africa', Journal of Theology for Southern Africa 113, 41-60.

Kretzschmar, L., 2004, 'The importance of moral and spiritual formation in 21st century Africa', in E. Conradie (ed.), African Christian theologies in transformation, pp. 86-110, Ecumenical Foundation of South Africa (EFSA), Stellenbosch.

Kretzschmar, L., 2005, Ethics and spirituality, Study guide for CGM 304V, University of South Africa, Pretoria.

Kretzschmar, L., 2006, 'The indispensability of spiritual formation for Christian leaders', Missionalia 34(2-3), 338-361.

Kretzschmar, L., 2007, 'The formation of moral leaders in South Africa: A Christianethical analysis of some essential elements', Journal of Theology for Southern Africa 128, 18-36.

Kretzschmar, L., 2008, 'Christian spirituality in dialogue with secular and African spiritualities with reference to moral formation and agency', Theologia Viatorum 32(1), 63-96.

Kretzschmar, L., 2012, 'The Christian formation of South African believers for engagement with state and society', in W. Bentley \& D.A. Forster (eds.), Between capital and cathedral: Essays on church-state relationships, pp. 137-171, Research Institute for Theology and Religion, University of South Africa, Pretoria.

Kretzschmar, L., 2014, 'Entering through the narrow gate and walking the hard road: The role of Christian leaders in exposing moral evil in the South African workplace', Koers - Bulletin for Christian Scholarship 79(2), art. \#2120, 9 pages. https://doi. org/10.4102/koers.v79i2.2120

Kretzschmar, L., 2015, 'The education of prospective ministers as an invitation to life: Moving from moral failure to moral excellence through a process of moral formation', In die Skriflig 49(1), art.\#1868, 10 pages. https://doi.org/10.4102/ids. v49i1.1868

Kretzschmar, L., 2016, 'Beyond milk: The moral failure and ongoing formation of lay Christian leaders in the Church and society', in E. Henry (ed.) Baptist faith and witness, book 5: Papers of the commission on mission, evangelism and theological witness, book 5: Papers of the commission on mission, evangelism and theological
reflection of the Baptist World Alliance 2010-2015, pp. 127-143, Baptist World reflection of the Baptist Wor
Alliance, Falls Church, VA.

Kretzschmar, L., 2019, 'An ethical analysis of "big man" and "inner ring" leadership in South Africa: The example of Jacob Zuma and the resistance of Thuli Madonsela' in S. Jung, V. Kessler, L. Kretzschmar \& E. Meier (eds.), Metaphors for leading Leading by metaphors, pp. 17-27, Vandenhoeck \& Ruprecht (V \& R Unipress), Göttingen.

Kretzschmar, L. \& Tuckey, C.E., 2017, 'The role of relationship in moral formation: An analysis of three tertiary theological education institutions in South Africa', In die Skriflig 51(1), a2214. https://doi.org/10.4102/ids.v51i1.2214

Kudadjie, J.N., 1996, 'African spirituality', in C.W. Du Toit (ed.), Spirituality in religions: Profiles and perspectives, pp. 62-82, Research Institute of Theology and Religion, University of South Africa, Pretoria.

Kunhiyop, S.W., 2008, African Christian ethics, Zondervan Academic, Grand Rapids, MI.

Leech, K., 1980, True prayer: An introduction to Christian spirituality, Sheldon Press, London.

Maathai, W., 2004, Unbowed: A memoir, Knopf Publishing Group, New York, NY.

Magesa, L., 2010, 'African Christian spirituality', in D.B. Stinton (ed.), African theology on the way: Current conversations, pp. 68-78, Society for the Promotion of Christian Knowledge, London.

Maluleke, T.S., 2010a, 'A post-colonial South African church: Problems and promises', in D.B. Stinton (ed.), African theology on the way: Current conversations, pp. 150-160, Society for the Promotion of Christian Knowledge, London.

Maluleke, T.S., 2010b, 'Of Africanised bees and Africanised churches: Ten theses on African Christianity', Missionalia 38(3), 369-379.

Manton, J., 1997, 'Spiritual formation in theological education', British Journal of Education 9(2), 3-20. https://doi.org/10.1080/1352741X.1997.11674102

Mbuy-Beya, B., 2010, 'African spirituality: A cry for life', in D.B. Stinton (ed.), African theology on the way: Current conversations, pp. 65-76, Society for the Promotion of Christian Knowledge, London.

Merten, M., 2019, State capture wipes out a third of SA's R4.8 trillion GDP - Never mind trust, confidence and lost opportunity, viewed 30 October 2019, from https://www.dailymaverick.co.za/article/2019-03-01-state-capturehttps://www.dailymaverick.co.za/article/2019-03-01-state-capturewipes-out-third-
opportunity/. 
Morove, M.F., 2009, African ethics: An anthology of comparative and applied ethics, University of Natal Press, Scottsville.

Mosala, I. \& Thagale, B., 1986, The unquestionable right to be free, Skotaville and ICT, Johannesburg.

Motlhabi, M., 2008, African theology/black theology in South Africa: Looking back, moving on, University of South Africa Press, Pretoria.

Mugambi, J.N.K. \& Nasimiyu-Wasike, A. (eds.), 1999, Moral and ethical issues in African Christianity, Acton, Nairobi.

Mungwini, P., 2011, 'The challenges of revitalizing an indigenous and Afrocentric moral theory in postcolonial education in Zimbabwe', Educational Philosophy and Theory 43(7), 773-787. https://doi.org/10.1111/j.14695812.2009.00564.x

Mwikamba, C.M., 1999, 'Changing morals in Africa', in J.N.K. Mugambi \& A. NasimiyuWasike (eds.), Moral and ethical issues in African Christianity, pp. 83-106, Acton Nairobi.

Naidoo, M., 2016, 'Overcoming alienation in Africanising theological education', HTS Teologiese Studies/Theological Studies 72(1), art. \#3062, 8 pages. https://doi. org/10.4102/hts.v72i1.3062

Nkansah-Obrempong, J., 2013, Foundations for African theological ethics, Langham Monographs, Carlisle.

Ntlha, M., 2009, 'Ethics and the Church in Africa', in L. Kretzschmar, W. Bentley \& A Van Niekerk (eds.), What is a good life? An introduction to Christian ethics in 21st century Africa, pp. 287-297, Acad SA, Kempton Park.

Olupona, J.K. (ed.), 2001, African spirituality: Forms, meanings and expressions, Herder \& Herder, New York, NY.

Omarjee, L., 2019, Ramaphosa says state capture cost SA more than R500 bn, overseas criminals will be brought to book, viewed 16 October 2019, from https://www.fin24.com/Economy/South-Africa/ramaphosa-says-statecapture-cost-sa-more-than-r500bn-overseas-criminals-will-be-brought-tobook-20191014.
Pato, L.L., 1996, 'Being fully human: A traditional African culture and spiritual perspective' in C.W. Du Toit (ed.), Spirituality in religions: Profiles and perspectives, pp. 109-121, Research Institute of Theology and Religion, University perspectives, pp. 109-121,
of South Africa, Pretoria.

Pato, L.L., 2002, 'African spirituality and transformation in South Africa', in C.Kourie \& L. Kretzschmar (eds.), Christian spirituality in South Africa, pp. 92-99, Cluster, Pietermaritzburg.

Peta, B., 2019, 'No tears for Mugabe', viewed 24 October 2019, from https://www. pressreader.com/south-africa/sunday-times-1107/20190922/282050508782160.

Phiri, I.A., Werner, D., Kaunda, C. \& Owino, K., 2016, Anthology of African Christianity, World Council of Churches, Geneva.

Rakoczy, S., 2017, 'The mission spirituality of "Laudato Si": Ecological conversion and the world Church', Grace \& Truth 34(2), 66-78.

Sebahene, A., 2017, Corruption mocking at justice: A theological-ethical perspective on public life in Tanzania and its implications for the Anglican Church of Tanzania, Langham Monographs, London.

Stinton, D.B. (ed.), 2010, African theology on the way: Current conversations, Society for the Promotion of Christian Knowledge, London.

Van der Ven, J.A., 1998, Formation of the moral self, Eerdmans, Grand Rapids, MI.

Van der Walt, B.J., 2003, 'Morality in Africa: Yesterday and today: The reasons for the contemporary crisis', In die Skriflig 37(1), 51-71. https://doi.org/10.4102/ids. v37i1.458

Vest, N., 2000, Desiring life: Benedict on wisdom and the good life, Cowley, Boston, MA.

Willard, D., 1988, The spirit of the disciplines: Understanding how God changes lives, Hodder and Stoughton, London.

Willard, D., 1998, 'Spiritual disciplines, spiritual formation, and the restoration of the soul', Journal of Psychology \& Theology 26(1), 101-109. https://doi. org/10.1177/009164719802600108

Wright, N.T., 2010, After you believe: Why Christian character matters, HarperOne, New York, NY. 